\title{
Eroded dentin does not jeopardize the bond strength of adhesive restorative materials
}

\section{Janaina Barros Cruz ${ }^{(a)}$ Tathiane Larissa Lenzi ${ }^{(b)}$ Tamara Kerber Tedesco(b) Camila de Almeida Brandão Guglielmi(b) \\ Daniela Prócida Raggio(b)}

(a) Department of Pediatric Dentistry, School of Dentistry, São Leopolodo Mandic Dental Research Center, Campinas, SP, Brazil.

(b) Department of Orthodontics and Pediatric Dentistry, School of Dentistry, University of São Paulo - USP, São Paulo, SP, Brazil.
Declaration of Interests: The authors certify that they have no commercial or associative interest that represents a conflict of interest in connection with the manuscript.

Corresponding author:

Daniela Prócida Raggio

E-mail:danielar@usp.br

Received for publication on Feb 15, 2012 Accepted for publication on Apr 23, 2012

\begin{abstract}
This in vitro study evaluated the bond strength of adhesive restorative materials to sound and eroded dentin. Thirty-six bovine incisors were embedded in acrylic resin and ground to obtain flat buccal dentin surfaces. Specimens were randomly allocated in 2 groups: sound dentin (immersion in artificial saliva) and eroded dentin ( $\mathrm{pH}$ cycling model - $3 \times /$ cola drink for 7 days). Specimens were then reassigned according to restorative material: glass ionomer cement (Ketac ${ }^{\mathrm{TM}}$ Molar Easy Mix), resin-modified glass ionomer cement $\left(V_{\text {Vitremer }}^{\mathrm{TM}}\right.$ ) or adhesive system with resin composite (Adper Single Bond $2+$ Filtek Z250). Polyethylene tubes with an internal diameter of $0.76 \mathrm{~mm}$ were placed over the dentin and filled with the material. The microshear bond test was performed after $24 \mathrm{~h}$ of water storage at $37^{\circ} \mathrm{C}$. The failure mode was evaluated using a stereomicroscope $(400 \times)$. Bond strength data were analyzed with two-way ANOVA and Tukey's post hoc tests $(\alpha=0.05)$. Eroded dentin showed bond strength values similar to those for sound dentin for all materials. The adhesive system showed the highest bond strength values, regardless of the substrate $(\mathrm{p}<0.0001)$. For all groups, the adhesive/ mixed failure prevailed. In conclusion, adhesive materials may be used in eroded dentin without jeopardizing the bonding quality. It is preferable to use an etch-and-rinse adhesive system because it shows the highest bond strength values compared with the glass ionomer cements tested.
\end{abstract}

Descriptors: Tooth Erosion; Dental Materials; Shear Strength; Dentin.

\section{Introduction}

An increase in erosive tooth wear ${ }^{1,2}$ associated with a decline in dental caries incidence ${ }^{3}$ has attracted research interest to this field. Lifestyle changes and the consumption of soft drinks / acidic foods seem to be the factors responsible for this condition. ${ }^{4,5}$ In the initial stages, the erosion lesions are limited to the enamel; however, dentin exposure can also occur as the lesions progress. ${ }^{6}$ In such cases, adhesive restorative materials, such as glass ionomer cements and resin composites, are able to reestablish tooth contour, function and aesthetics, and protect the exposed dentin. $^{7}$

Several studies have evaluated the modification that occurs on the surface of restorative materials after an erosive challenge. Deleterious effects have been documented in properties such as hardness, ${ }^{8}$ wear depth, ${ }^{9,10}$ morphology ${ }^{11}$ and surface roughness. ${ }^{12}$ However, there is a lack of studies 
focusing on the bond strength properties of dental materials applied to eroded dentin.

The erosive challenge leads to greater wear ${ }^{13}$ and reduction in hardness ${ }^{8}$ of the dentin substrate with the formation of spatial areas with damaged apatite that exhibit local structural alteration, namely broken and/or loosened P-O--Ca atomic linkages. ${ }^{14}$ The lower hydroxyapatite and calcium content is expected to interfere with the bond strength of glass ionomer cements due to their mechanism of action. Alterations such as dentinal tubule opening, removal of dentinal plugs and the organic portion of intertubular dentin, that increase the tubules' diameter and cause collagen exposure, have also been reported..$^{15}$

Because the erosion challenge causes alterations in dentin, we hypothesize that restorative materials may act differently in sound and eroded substrates. However, to the best of our knowledge, no previous study has investigated the bond strength of adhesive materials to eroded substrates. While a number of studies focus on erosive tooth wear prevalence, ${ }^{1,2}$ few seek information about their treatment. Therefore, the aim of this study was to evaluate the bond strength of adhesive restorative materials to sound and eroded dentin.

\section{Methodology \\ Tooth selection and preparation}

Thirty-six bovine incisors stored at $4{ }^{\circ} \mathrm{C}$ were used in this study. The roots were removed using a low-speed diamond disc in a cutting machine (Labcut 1010, Extec Co., Enfield, USA), and crowns were embedded in self-curing acrylic resin inside PVC rings (JET Clássico ${ }^{\circledR}$, São Paulo, Brazil). The exposed buccal surfaces were ground under water with 320 grit $\mathrm{SiC}$ paper to obtain a flat dentin surface and further polished with 600 grit $\mathrm{SiC}$ paper for $60 \mathrm{~s}$ to create a standardized smear layer. ${ }^{16}$

\section{Erosive Challenge}

Specimens were randomly allocated into 2 groups:

- (1) immersion in artificial saliva during the experimental period (control group - sound dentin, $\mathrm{n}=18)$;

- (2) erosion challenge according to a $\mathrm{pH}$-cycling model (eroded dentin, $\mathrm{n}=18$ ) .

Three $\mathrm{pH}$-cycles were performed at 8, 14 and 20 hours for seven days. Teeth were immersed in a cola drink (Coca-Cola, [pH: 2.6, phosphate: $5.43 \mathrm{mM}$ Pi, calcium: $0.84 \mathrm{mM} \mathrm{Ca}^{2+}$, fluoride: $0.13 \mathrm{ppm} \mathrm{F}$, titratable acid: $40.0 \mathrm{mmol} / \mathrm{L} \mathrm{OH}^{-}$to $\mathrm{pH} 5.5$ and $83.6 \mathrm{mmol} / \mathrm{L} \mathrm{OH}^{-}$to $\mathrm{pH}$ 7.0], Spal, Porto Real, Brazil) for $5 \mathrm{~min}(30 \mathrm{~mL}$ per tooth) and were kept in artificial saliva $\left(1.5 \mathrm{mmol} \mathrm{L}-1 \mathrm{Ca}\left[\mathrm{NO}_{3}\right]_{2} \cdot 4 \mathrm{H}_{2} \mathrm{O}\right.$, $0.9 \mathrm{mmol} \mathrm{L}^{-1} \mathrm{NaH}_{2} \mathrm{PO}_{4} \cdot 2 \mathrm{H}_{2} \mathrm{O}, 150 \mathrm{mmol} \mathrm{L}^{-1} \mathrm{KCl}$, $0.1 \mathrm{~mol} \mathrm{~L}^{-1}$ Tris buffer, $0.03 \mathrm{ppm} \mathrm{F,} \mathrm{pH} \mathrm{7.0,} 30 \mathrm{~mL}$ per tooth) between erosive cycles, under agitation and at room temperature. During the remaining time, teeth were also kept in artificial saliva. ${ }^{9}$

\section{Restorative procedures}

Teeth from each dentin substrate (sound or eroded) were randomly reassigned into 3 subgroups according to adhesive restorative material used:

- glass ionomer cement - GIC (Ketac ${ }^{\mathrm{TM}}$ Molar Easy Mix),

- resin-modified GIC (Vitremer ${ }^{\mathrm{TM}}$ ) or

- etch-and-rinse adhesive system associated with resin composite (Adper Single Bond $2+$ Filtek Z250).

This resulted in a $2 \times 3$ factorial experimental design with 6 teeth in each subgroup formed from the crossing of two factors:

- substrate and

- material.

Table 1 displays the components and application mode of adhesive restorative materials used in the experiment.

After surface pretreatment, polyethylene tubes (Micro-bore ${ }^{\circledR}$ Tygon S-54-HL Medical Tubing, SaintGobain Performance Plastics, Akron, USA) with an internal diameter of $0.76 \mathrm{~mm}$ and a $1.0-\mathrm{mm}$ height were filled with one of the restorative materials and placed on the bonded area. Tubes were covered with a matrix strip and gently pressed with a glass slide. For each tooth, 3 specimens were built up. Surface protection was performed for glass ionomer cement according to the manufacturer's instructions. For 
Table 1 - Adhesive materials: manufacturer, composition, application mode and surface protection.

\begin{tabular}{|c|c|c|c|}
\hline Material and manufacturer & Composition & Application mode & Surface protection \\
\hline $\begin{array}{c}\text { Ketac }^{\mathrm{TM}} \text { Molar Easy Mix } \\
\text { (3M ESPE, Seefeld, } \\
\text { Germany) }\end{array}$ & $\begin{array}{l}\text { Ketac }^{\mathrm{TM}} \text { Conditioner: polyacrylic acid } \\
\qquad(25 \%) \\
\text { Powder: calcium aluminum-lanthanum- } \\
\text { fluorosilicate glass, acrylic acid-maleic acid } \\
\text { copolymer, pigments } \\
\text { Liquid: water, acrylic acid-maleic acid } \\
\text { copolymer, tartaric acid }\end{array}$ & $\begin{array}{l}\text { (1) Apply Ketac Conditioner for } 10 \mathrm{~s} \text {; } \\
\text { (2) rinse with a copious amount of water; } \\
\text { (3) gently air-dry (5 s), leaving a moist } \\
\text { surface; (4) dose } 1 \text { drop of liquid and } 1 \\
\text { powder scoop, mix up to } 30 \mathrm{~s} \text {; (5) apply to } \\
\text { dentin surface }\end{array}$ & $\begin{array}{l}\text { Solid } \\
\text { petroleum } \\
\text { jelly }\end{array}$ \\
\hline $\begin{array}{c}\text { Vitremer }^{\mathrm{TM}} \\
\text { (3M ESPE, Seefeld, } \\
\text { Germany) }\end{array}$ & $\begin{array}{l}\text { Primer: Vitrebond copolymer, HEMA, } \\
\text { ethanol and photoinitiators } \\
\text { Powder: fluoroaluminosilicate glass, } \\
\text { potassium persulfate and ascorbic acid } \\
\text { Liquid: polyalkenoic acid, HEMA, } \\
\text { dimethacrylate, photoinitiator, water }\end{array}$ & $\begin{array}{c}\text { (1) Apply primer for } 30 \mathrm{~s} \text {; (2) gently air-dry } \\
\text { with syringe; (3) light-cure for } 20 \mathrm{~s} \text {; (4) dose } \\
1 \text { drop of liquid and } 1 \text { powder scoop, mix up } \\
\text { to } 45 \mathrm{~s} \text {; (5) apply to dentin surface; (6) light- } \\
\text { cure for } 40 \mathrm{~s}\end{array}$ & $\begin{array}{l}\text { Finishing } \\
\text { gloss }\end{array}$ \\
\hline $\begin{array}{l}\text { Adper Single Bond } 2 \\
\quad \text { (St. Paul, USA) }\end{array}$ & $\begin{array}{c}\text { HEMA, water, ethanol, Bis-GMA, } \\
\text { dimethacrylates, amines, methacrylate } \\
\text { functional copolymer of polyacrylic and } \\
\text { polyitaconic acids, } 10 \% \text { by weight of } 5 \\
\text { nanometer-diameter spherical silica particles } \\
\text { Bis-GMA, TEG-DMA, zirconia, silica }\end{array}$ & $\begin{array}{l}\text { (1) Etch for } 15 \mathrm{~s} \text {; (2) rinse with water spray } \\
\text { for } 15 \mathrm{~s} \text {, leaving tooth moist; (3) active } \\
\text { application of two consecutive coats of the } \\
\text { adhesive with a fully saturated brush tip, } \\
\text { dry gently for } 2-5 \mathrm{~s} \text {; (4) light-cure for } 10 \mathrm{~s} \text {; } \\
\text { (5) apply one increment of composite resin } \\
\text { and light-cure for } 20 \mathrm{~s}\end{array}$ & $\begin{array}{c}\text { Not } \\
\text { recommended }\end{array}$ \\
\hline
\end{tabular}

HEMA: 2-hydroxyethylmethacrylate; Bis-GMA: bis-phenol A diglycidyl methacrylate; TEG-DMA: triethylene glycol dimethacrylate.

the light-cured materials, halogen light curing was used (Jetlite 4000 Plus, J. Morita USA Inc., USA) with a $600 \mathrm{~mW} / \mathrm{cm}^{2}$ power density.

After storage in distilled water at $37^{\circ} \mathrm{C}$ for $24 \mathrm{~h}$, the polyethylene tubes were removed using a surgical blade, resulting in cylindrical specimens with a cross-sectional area of approximately $0.45 \mathrm{~mm}^{2}$. Specimens were examined under a stereomicroscope at $20 \times$ magnification, and those with interfacial gaps, bubble inclusion or other defects were excluded and replaced.

\section{Microshear bond strength test ( $\mu$ SBS)}

The specimens were then attached to the microshear bond universal testing machine (Kratos Industrial Equipment, Cotia, SP, Brazil), and a shear load was applied with a thin steel wire $(0.20 \mathrm{~mm}$ diameter) at a crosshead speed of $1.0 \mathrm{~mm} / \mathrm{min}$ until failure. Care was taken to keep the restorative material cylinder in line with the center of the load cell and the wire loop parallel to the load cell movement direction and to the bonding interface. The microshear bond strength was calculated and expressed in $\mathrm{MPa}$.

\section{Failure mode}

The failure mode was determined with a stereomicroscope with 400× magnification (Discovery V20, Zeiss, Oberkochen, Germany) and classified as adhesive/mixed failure (presence of dentin or resin composite/GIC adjacent to interface) or cohesive failure (failure in dentin or resin composite/GIC).

\section{Statistical analysis}

The experimental unit in the current study was the tooth. Thus, the mean $\mu$ SBS values of all specimens from the same tooth were averaged for statistical analysis. A normal data distribution and an equality of variances were assumed after Kolmogorov-Smirnov and Barlett's tests. The $\mu$ SBS means were analyzed by two-way ANOVA and Tukey post hoc test. The significance level was set at $\mathrm{p}<0.05$. All statistical analyses were performed using Minitab 16 software (Minitab Inc., State College, USA). 
Figure 1 - Distribution (\%) of failure mode for experimental groups (SB: Adper Single Bond 2; VI: Vitremer ${ }^{\mathrm{TM}}$; KM: Ketac ${ }^{\mathrm{TM}}$ Molar Easy Mix).

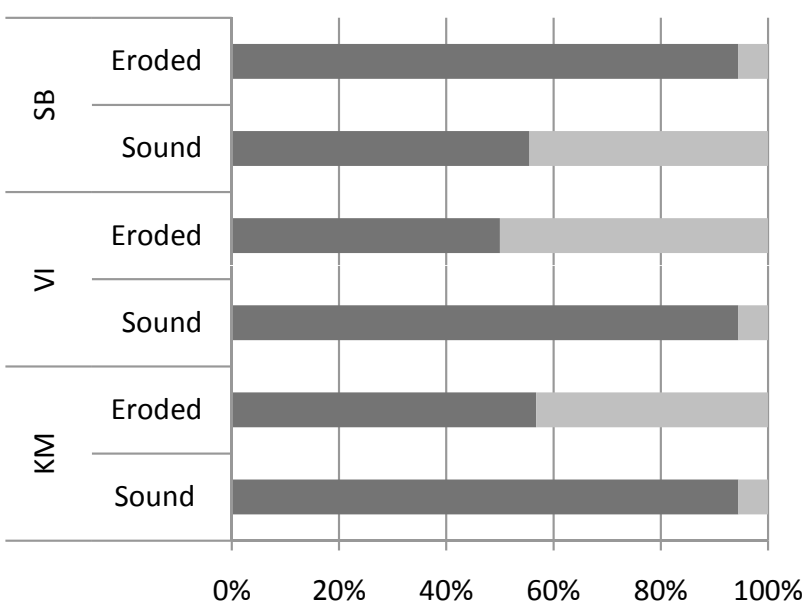

adhesive/mixed

$\square$ Cohesive in resin/GIC

\section{Results}

The microshear bond strength means $(\mathrm{MPa})$ and standard deviations for all experimental groups are presented in Table 2. Only the main factor (adhesive material) was statistically significant $(\mathrm{p}<0.0001)$. The adhesive system showed the highest bond strength values, regardless of the substrate. No difference in bond strength was found between eroded or sound dentin using any of the materials.

The distribution of the failure mode is summarized in Figure 1. For all groups, adhesive/mixed failure prevailed. No cohesive failure in dentin was observed.

\section{Discussion}

Increased erosion prevalence has been clinically observed, particularly in enamel. ${ }^{1,2}$ Although deep lesions are less common, without controlling etiological factors, they can extend to dentin. Such situations require a restorative procedure, and it is important to know the performance of adhesive restorative materials in this type of substrate.

To simulate dental erosion, dynamic erosive $\mathrm{pH}$-cycling using a cola drink was employed. This beverage has a high erosive potential due to its low $\mathrm{pH}$ and low fluoride/calcium concentrations. ${ }^{4} \mathrm{Al}-$ though in vitro models are unable to thoroughly simulate the oral environment, especially with respect to important aspects of the erosion process, such as salivary flow, pellicle formation and buffering capacity, ${ }^{17}$ the adopted protocol simulates a typical intake of individuals considered to be at risk for
Table 2 - Microshear bond strength means and standard deviations (MPa) for the experimental groups.

\begin{tabular}{c|c|c|c}
\hline \multirow{2}{*}{ Substrate } & \multicolumn{3}{|c}{ Material } \\
\cline { 2 - 4 } & Vitremer & $\begin{array}{c}\text { Adper Single } \\
\text { Bond 2 }\end{array}$ & $\begin{array}{c}\text { Ketac Molar } \\
\text { Easy Mix }\end{array}$ \\
\hline Sound dentin & $13.9 \pm 7.1^{\mathrm{b}}$ & $17.1 \pm 3.4^{\mathrm{a}}$ & $7.5 \pm 1.4^{\mathrm{b}}$ \\
\hline Eroded dentin & $9.4 \pm 6.3^{\mathrm{b}}$ & $17.5 \pm 4.2^{\mathrm{a}}$ & $9.8 \pm 3.0^{\mathrm{b}}$ \\
\hline
\end{tabular}

Different superscript letters indicate statistically significant differences $(p<0.05)$.

dental erosion. ${ }^{13}$

The replacement of human teeth with bovine dental hard tissues has been recommended, especially for studies that evaluate bonding mechanisms. ${ }^{18,19}$ Schilke et al..$^{20}$ showed that human and bovine dentin present similar characteristics when analyzed by scanning electron microscopy, such as number and diameter of tubules per $\mathrm{mm}^{2}$ and presence of a collagen matrix. Moreover, bovine teeth are easier to obtain in large numbers in good condition, and they present less variation in composition. ${ }^{21}$ Bovine dentin can be a suitable substitute for human dentin in bonding tests. For these reasons, bovine dentin has been chosen for the present study.

Furthermore, the microshear test was used to evaluate bond strength because the literature affirms that the "micro" tests are the best at verifying the performance of contemporaneous materials due to the high bond strength values, which are not possible to measure with precision in "macro" tests (such as shear and tensile bond strength tests). ${ }^{22}$ The microshear bond strength test showed some advan- 
tages-a reduced demand during the specimen preparation, the standardization of bond test areas by the use of a tube with a known diameter and the use of fewer teeth to perform the study-all of which justify its choice. ${ }^{23}$

The erosion process can lead to the removal of dentinal plugs and organic intertubular dentin, resulting in an increase in tubule diameter and collagen exposure. ${ }^{15}$ These differences between sound and eroded dentin might interfere with the bonding properties of adhesive materials. In spite of that, this difference in performance was not observed in the current study. Eroded dentin showed similar bond strength values compared with sound dentin. It is speculated that the adhesive materials were able to promote complete micromechanical interlocking in a similar way for both substrates, even when a greater degree of demineralization had occurred, as in the case of the eroded dentin.

The adhesive system showed better bonding performance to dentin, corroborating a previous study, ${ }^{24}$ and this difference was noted for both substrates. This can be attributed to the mechanism of the etch-and-rinse adhesive system, which results in smear layer removal, allowing the resin to penetrate the tubules and to infiltrate the underlying demineralized dentin. ${ }^{25}$ It is also known that the bonding mechanism in dentin is carried out by hybrid layer formation, which is composed of residual hydroxyapatite, resin and collagen. After etching, the resin monomers penetrate the water-filled spaces between dentin collagen fibers that used to be filled with hydroxyapatite crystals. In terms of the dentin substrate, it is hypothesized that the mineral content may be not as essential as it is for the enamel when using an etch-and-rinse strategy.

The bonding performance of the resin-modified GIC was similar to that of the conventional GIC, and the erosive process also did not interfere with the bond strength. Despite the presence of resin monomers that may enhance physical properties, the bonding mechanism for resin-modified GIC does not differ much from that for the conventional GIC. The former still presents the chemical adhesion to dental structures that is unique to glass ionomer cements. Some studies demonstrated higher bond strengths values for the resin-modified GIC and have associated this finding to the use of an acidic primer. ${ }^{26,27}$ This component is able to modify the smear layer and wet the dental surface to improve the interaction between the material and the substrate. However, this result was not observed in the current study, possibly because of the prior application of polyacrylic acid to the dentin substrate before the use of the conventional GIC. This step is recommended to increase the bond strength because it promotes a superficial cleaning, which enhances the micromechanical and chemical interaction between the GIC and the hydroxyapatite. ${ }^{28}$

Although the higher demineralization of eroded dentin due to the lower hydroxyapatite and calcium content did not negatively influence the bond strength of glass ionomer cements, this aspect may be related to changes in the failure pattern. A higher percentage of cohesive GIC failure was observed in the eroded substrate. The reasons are not clear, but some reports suggest that there was no correlation between the cohesive material failure and the bond strength. ${ }^{29}$ It was suggested that the failure mode was affected by the material properties of all components of the bonded joint-i.e., GIC, hybrid-like layer and dentin-and the mechanics of the test assembly. Thus, the eroded dentin, softer and more porous than sound dentin and associated with the presence of possible air bubbles in GIC that can act as stress points, increased the likelihood of cohesive fracture within the cement. ${ }^{24}$

Conversely, in this study, few cohesive fractures in GICs in sound dentin were observed, in contrast with a previous study ${ }^{24}$ that used a microtensile test. The microshear bond test does not require cutting procedures during the specimens' preparation phase; the cutting may cause damage to brittle materials and can result in fractures prior to adhesive failure. $^{30}$

Furthermore, because the chemical interaction might be beneficial in reducing the hydrolytic degradation and thus enhancing the restoration longevity, further studies should be conducted to obtain a better understanding of the durability of the bond to eroded dentin to find a reliable correlation with clinical situations. 


\section{Conclusion}

Adhesive materials may be used in eroded dentin without jeopardizing the bonding quality. It is preferable to use an etch-and-rinse adhesive system

\section{References}

1. Kazoullis S, Seow WK, Holcombe T, Newman B, Ford D. Common dental conditions associated with dental erosion in school children in Australia. Pediatr Dent. 2007 JanFeb;29(1):33-9.

2. Murakami C, Oliveira LB, Sheiham A, Corrêa MSNP, Haddad AE, Bönecker M. Risk indicators for erosive tooth wear in brazilian preschool children. Caries Res. 2011;45(2):121-9.

3. Bönecker M, Ardenghi TM, Oliveira LB, Sheiham A, Marcenes W. Trends in dental caries in 1- to 4-year-old children in a Brazilian city between 1997 and 2008. Int J Paediatr Dent. 2010 Mar;20(2):125-31.

4. Lussi A, Jaeggi T, Zero D. The role of diet in the aetiology of dental erosion. Caries Res. 2004;38(1):34-44.

5. Imfeld T. Dental erosion. Definition, classification and links. Eur J Oral Sci. 1996 Apr;104(2):151-5.

6. Lambrechts P, Debels E, Van Landuyt K, Peumans M, Van Meerbeek B. How to simulate wear? Overview of existing methods. Dent Mater. 2006 Aug;22(8):693-701.

7. Jaeggi T, Gruninger A, Lussi A. Restorative therapy of erosion. Monogr Oral Sci. 2006;20:200-14.

8. Wongkhantee S, Patanapiradej V, Maneenut C, Tantbirojn D. Effect of acidic food and drinks on surface hardness of enamel, dentine, and tooth-coloured filling materials. J Dent. 2006 Mar;34(3):214-20.

9. Francisconi LF, Honório HM, Rios D, Magalhães AC, Machado MA, Buzalaf MA. Effect of erosive $\mathrm{pH}$ cycling on different restorative materials and on enamel restored with these materials. Oper Dent. 2008 Mar-Apr;33(2):203-8.

10. Rios D, Honório HM, Francisconi LF, Magalhães AC, Machado MA, Buzalaf MA. In situ effect of an erosive challenge on different restorative materials and on enamel adjacent to these materials. J Dent. 2008 Feb;36(2):152-7.

11. Honório HM, Rios D, Francisconi LF, Magalhães AC, Machado MA, Buzalaf MA. Effect of prolonged erosive $\mathrm{pH}$ cycling on different restorative materials. J Oral Rehabil. 2008 Dec;35(12):947-53.

12. Badra VV, Faraoni JJ, Ramos RP, Palma-Dibb RG. Influence of different beverages on the microhardness and surface roughness of resin composites. Oper Dent. 2005 MarApr;30(2):213-9.

13. Turssi CP, Hara AT, Domiciano SJ, Serra MC. Study on the potential inhibition of root dentine wear adjacent to fluoride-containing restorations. J Mater Sci Mater Med. 2008 Jan;19(1):47-51. because it shows the highest bond strength values compared with the glass ionomer cements tested.

14. Wang X, Mihailova B, Klocke A, Heidrich S, Bismayer U. Effect of artificial saliva on the apatite structure of eroded enamel. Int J Spectrosc. 2011; 2011 [cited 2012 Feb 15]. Available from: http://www.hindawi.com/journals/ijs/2011/236496/. doi:10.1155/2011/236496.

15. Prati C, Montebugnoli L, Suppa P, Valdrè G, Mongiorgi R. Permeability and morphology of dentin after erosion induced by acid drinks. J Periodontol. 2003 Apr;74(4):428-36.

16. Reis A, Albuquerque M, Pegoraro M, Mattei G, Bauer JR, Grande RH, et al. Can the durability of one-step self-etch adhesives be improved by double application or by an extra layer of hydrophobic resin?. J Dent. 2008 May;36(5):309-15.

17. Sonju Clasen AB, Ogaard B, Duschner H, Ruben J, Arends J, Sönju T. Caries development in fluoridated and non-fluoridated deciduous and permanent enamel in situ examined by microradiography and confocal laser scanning microscopy. Adv Dent Res. 1997;11(4):442-7.

18. Reis AF, Giannini M, Kavaguchi A, Soares JC, Line SR. Comparison of microtensile bond strength to enamel and dentin of human, bovine, and porcine teeth. J Adhes Dent. 2004 Summer;6(2):117-21.

19. Krifka S, Börzsönyi A, Koch A, Hiller KA, Schmalz G, Friedl KH. Bond strength of adhesive systems to dentin and enamel - Human vs. bovine primary teeth in vitro. Dent Mater. 2008 Jul;24(7):888-94.

20. Schilke R, Lisson JA, Bauss O, Geurtsen W. Comparison of the number and diameter of dentinal tubules in human and bovine dentine by scanning electron microscopic investigation. Arch Oral Biol. 2000 May;45(5):355-61.

21. Edmunds DH, Whittaker DK, Green RM. Suitability of human, bovine, equine, and ovine tooth enamel for studies of artificial bacterial carious lesions. Caries Res. 1988;22(6):32736.

22. Pashley DH, Sano H, Ciucchi B, Yoshiyama M, Carvalho RM. Adhesion testing of dentin bonding agents: a review. Dent Mater. 1995;11(2):117-25.

23. Shimada Y, Senawongse P, Harnirattisai C, Burrow MF, Nakaoki Y, Tagami J. Bond strength of two adhesive systems to primary and permanent enamel. Oper Dent. 2002;27(4):4039.

24. Burrow MF, Nopnakeepong U, Phrukkanon S. A comparison of microtensile bond strengths of several dentin bonding systems to primary and permanent dentin. Dent Mater. 2002 May;18(3):239-45. 
25. Brackett WW, Covey DA, Germain HA Jr. One-year clinical performance of a self-etching adhesive in class $\mathrm{V}$ resin composites cured by two methods. Oper Dent. 2002 MayJun;27(3):218-22.

26. Mitra SB, Kedrowski BL. Long-term mechanical properties of glass ionomers. Dent Mater. 1994 Mar;10(2):78-82.

27. Abd El Halim S, Zaki D. Comparative evaluation of microleakage among three different glass ionomer types. Oper Dent. 2011 Jan-Feb;36(1):36-42.

28. Raggio DP, Sônego FG, Camargo LB, Marquezan M, Imparato JC. Efficiency of different polyacrylic acid concentrations on the smear layer, after ART technique, by Scanning
Electron Microscopy (SEM). Eur Arch Paediatr Dent. 2010 Oct;11(5):232-5.

29. Almuammar MF, Schulman A, Salama FS. Shear bond strength to six restorative materials. J Clin Pediatr Dent. 2001;25(3):221-5.

30. Bonifácio CC, Shimaoka AM, de Andrade AP, Raggio DP, van Amerongen WE, de Carvalho RC. Micro-mechanical bond strength tests for the assessment of the adhesion of GIC to dentine. Acta Odontol Scand. 2012 Jan 18; [Epub ahead of print]. Available from: http://www.researchgate.net/publication/221752988. 